\title{
Conciliationism and the Menace of Scepticism
}

\author{
DIEGO E. MACHUCA CONICET (Argentina)
}

ABSTRACT: It is sometimes claimed that conciliatory views on disagreement ultimately lead to either global or widespread scepticism. This is deemed to be a real problem for conciliationism either because scepticism of either kind is patently untenable or because it poses a serious threat to our intellectual and social lives. In this paper, I first argue that the alleged untenability of both types of scepticism is far from obvious and should therefore be established rather than taken for granted. Then, I show that those who reject both types of scepticism because of the threat they pose surprisingly confuse pragmatic reasons with epistemic reasons.

RÉSUMÉ : On dit parfois que les positions conciliationistes sur le désaccord aboutissent à un scepticisme soit global soit étendu. Ceci est considéré comme un réel problème pour le conciliationisme, soit parce que ces deux types de scepticisme sont manifestement insoutenables, soit parce qu'ils constituent une menace sérieuse pour nos vies intellectuelle et sociale. Dans cet article, je montre d'abord que le caractère prétendument insoutenable de ces deux types de scepticisme est loin d'être évident et devrait donc être démontré au lieu d'être simplement présupposé. Je montre ensuite que ceux qui rejettent ces deux types de scepticisme à cause de la menace qu'ils représentent confondent de manière étonnante raisons pragmatiques et raisons épistémiques.

\section{Introduction}

There are at present lively and fertile debates about the epistemic significance of disagreement, particularly of disagreement between so-called epistemic peers. My interest in these debates concerns the connection between peer disagreement and scepticism in its agnostic or Pyrrhonian variety, namely,

Dialogue 54 (2015), 469-488.

(C) Canadian Philosophical Association/Association canadienne de philosophie 2015 doi: $10.1017 / \mathrm{S} 0012217315000347$ 
whether suspension of judgment is the attitude we are compelled (psychologically or rationally) to adopt in the face of acknowledged peer disputes. ${ }^{1}$ In this paper, I focus on the objection sometimes raised to conciliationism according to which this view ultimately results in either total or widespread suspension of judgment. This is considered to be a real problem for conciliatory views on peer disagreement either because radical scepticism is a patently absurd or untenable stance or because it represents a serious threat to our intellectual and social lives. I will first argue that the alleged absurdity or untenability of radical scepticism is far from evident and should therefore be established rather than taken for granted (Section 2). I will then show that those who reject radical scepticism because of the threat it poses surprisingly confuse pragmatic reasons with epistemic reasons (Section 3). I will finally summarize my stance and consider some objections that might be levelled against it (Section 4).

Before proceeding, three remarks are in order. First, the reason I talk of global or widespread scepticism is that, while most of the authors whose views will be discussed explicitly refer to 'total,' 'wholesale,' or 'across-the-board' scepticism, others have in mind a more restricted sceptical stance that recommends suspension of judgment on a wide range of controversial issues. The important point for the purposes of this paper is that both kinds of scepticism are deemed by all these authors to be untenable or threatening.

Second, it might be argued that I should focus on conciliatory views on disagreement in general rather than on peer disagreement in particular because, for instance, the notion of epistemic peer is only applicable in the case of abstract or idealized disputes, but not in the case of actual or real-life disputes. The reason I will here focus mainly on conciliatory views on peer dispute is that the majority of the authors whose positions will be considered either examine whether those views in particular lead to wholesale or widespread scepticism, or refer to these forms of scepticism in the context of their analysis of peer disagreement. But for my present purposes nothing important hangs on whether the focus is on conciliatory views on peer dispute in particular or on conciliatory views that demand more generally that we suspend judgment in the face of the kind of entrenched and extensive controversies found in such areas as philosophy, religion, ethics, economics, and politics.

Third, my aim in this paper is not to argue that there is a sound peerdisagreement-based argument for global or widespread scepticism. Whether there is such an argument depends, among other things, on the definition and the scope of application of the notion of epistemic peer. In any case, as we will see below, some authors do think that it is at least in principle possible to construct such a sceptical argument. My aim is to call attention to what I take

1 Hereafter, whenever I talk of 'peer disagreement' or 'peer dispute,' I mean peer disagreements or disputes that are recognized or acknowledged as such by the rival parties. 
to be problematic aspects of the way in which scepticism has been treated by those authors. The question I consider could be couched in these terms: assuming as they do that it is possible to construct such a sceptical argument, have they rejected scepticism on adequate grounds? I am well aware that most people will disagree that some of the aspects in question are problematic, since most people believe that certain forms of scepticism are manifestly absurd or untenable or threatening. Still, I think that a dissenting voice is worth hearing.

\section{The Untenability of Scepticism}

Current epistemological discussions of disagreement have focused particularly on controversies between epistemic peers, that is, between individuals who are roughly equally familiar with the evidence and arguments bearing on the disputed issue and have similar cognitive skills or virtues. Two main views have been adopted regarding peer disagreement, namely, conciliationism and steadfastness, each comprising a number of variants. ${ }^{2}$ To put it in very general terms, whereas conciliationists claim that, in the face of a dispute with an epistemic peer, significant belief revision is required, non-conciliationists maintain that, in at least many cases, one can retain one's belief either with the same confidence or with slightly diminished confidence. Some conciliationists claim that the disputants should suspend judgment about the matter at hand, whereas others claim that the disputants should split the difference in the degrees of confidence in their respective beliefs. This depends on whether one adopts a coarse-grained or a fine-grained approach to doxastic attitudes. I will here examine the issue mainly in terms of the all-or-nothing model of belief rather than the graded model because I am interested in those views that recommend suspension of judgment, or at least a significant revision of one's beliefs, as the proper reaction to peer disagreement.

An objection often directed against conciliationism is that it leads to either global or widespread scepticism. This is deemed to pose two serious problems for conciliationists. In this section, I will examine the first problem, while in the next, I will look at the second. I will argue that the authors who call attention to these two problems have not as yet proven that scepticism is not a viable option in the face of either peer dispute or extensive persistent philosophical disagreement.

The first problem allegedly faced by conciliationism is that across-the-board scepticism is a patently absurd, incoherent, or implausible stance, and hence untenable and unworthy of serious consideration. For instance, David Enoch

2 Conciliatory views are defended by, e.g., Feldman (2006, 2007, 2009), Christensen (2007, 2011), Elga (2007), and Matheson (2009). Non-conciliatory views are adopted by, e.g., van Inwagen (1996, 2010), Plantinga (2000), Kelly (2005, 2010), and Sosa (2010). For an overview of the debate between conciliationists and nonconciliationists, see Machuca (2013c: Section 1). 
claims that the form of conciliationism known as the Equal Weight View $(E W V)^{3}$ entails "highly implausible consequences" that "count heavily against it," the main being the requirement to be epistemically spineless. ${ }^{4}$ In his discussion of the bootstrapping objection levelled against non-conciliationism by Adam Elga, he holds that EWV rests in the end on assumptions that naturally lead to scepticism, in which case this view "is - even worse than false-quite uninteresting." "Given that he does not explain why scepticism is uninteresting, I take it that the reason is that it is highly implausible, and given that he does not explain why it is highly implausible, I take it that he regards it as obvious that it is so.

A similar objection to conciliationism has been voiced by Michael Thune, who maintains that one of the reasons for rejecting this view is that it "seems wrongly to entail a sweeping "philosophical skepticism." "6 The problem with philosophical scepticism is that it is "intuitively false." Thune remarks that it is difficult to defend an intuitive claim of this sort, and that all he can say is that it just seems correct and highly plausible to him and others. Thus, for both Enoch and Thune, the falsity or implausibility of scepticism is so evident that they are exempt from offering arguments in support of its outright rejection. In other words, since scepticism is clearly untenable, there is no need of refutation.

The problem under consideration is deemed to be so acute that even some of the champions of conciliationism feel forced to make it clear that the suspension of judgment they propose is local, that is, restricted to very specific cases of disagreement. The clearest example is probably Elga, who maintains that, if across-the-board suspension of judgment were entailed by EWV, this would be an unwelcome consequence because this view would then lead to absurdity. ${ }^{8}$ I assume it is this low regard for scepticism that mainly explains why, despite putting forth the bootstrapping objection as a key reason for not endorsing any non-conciliationist stance, ${ }^{9}$ Elga makes a move that seems to fall victim to the very same objection. ${ }^{10} \mathrm{He}$ claims that the problem of spinelessness does not arise for EWV because, in real-world controversies, when someone disagrees

3 Roughly put, EWV claims that it is rationally required to give equal weight to the opinions of all the parties to a peer dispute when there is no reason for preferring one opinion over the others that is independent of the very disagreement between the parties.

Enoch (2010: 954-955).

5 Enoch (2010: 991-992).

6 Thune (2010: 369).

7 Thune (2010: 370).

8 Elga (2007: 484-485, 492, 497).

9 Elga (2007: 486-488).

10 Cf. Kelly (2010: 165-166). 
with one about the question whether $p$, he typically disagrees with one about many surrounding questions. Even setting aside one's reasoning about the question whether $p$, one thinks that one's opponent is not as likely as one is to be right about that question, and hence that he is not one's peer with respect to it. The reason is that, even if he is clever, well informed, and intellectually honest, one believes that he is wrong about the closely related questions. And if one set aside one's reasoning about the surrounding issues as well, there would be no common ground from which one could appraise one's dissenter's outlook. As a result, there are few cases of actual peer disagreement, and hence few cases in which one is required to suspend judgment. ${ }^{11}$ Elga's move seems problematic for the following reason. Let us suppose that my cousin Daniel, whom I have hitherto considered to be roughly as intelligent, knowledgeable, and intellectually honest as (I think) I am, disagrees with me about the question whether $p$, and that I realize that this disagreement is due to the fact that we disagree about several surrounding matters. It could be argued that, upon learning this, the right way to resolve the disagreement in question is not by simply assuming that I am the one who holds true beliefs about the related disputed issues - thereby taking the surrounding disagreements as evidence that Daniel is clearly not my peer about the question whether $p$-but by resolving the surrounding disagreements. This means that I must find out whether Daniel is familiar with the evidence and arguments bearing on the associated disputed issues and what his reasons are for holding the beliefs he holds. It is not enough that I simply think that Daniel is wrong about the issues closely linked to the disputed matter; I must also offer reasons for so thinking. Otherwise, it would be too easy for me to dismiss out of hand the views of anyone who significantly disagrees with me about a certain number of issues. Imagine what this would mean in the case of philosophy, where any controversy is closely linked with other controversies, so that it cannot be understood fully unless the surrounding controversies are considered. It does not sound a priori plausible to claim that another competent and knowledgeable philosopher with whom one is engaged in a dispute about a given matter is not actually one's peer simply because he also considerably disagrees with one about several or many closely related matters. In addition, if one considers one's opponent to be in general clever, well informed, and intellectually honest, then it seems that one does have reasons for thinking that he might well be right about the question whether $p$ and about at least some of the surrounding questions. ${ }^{12}$ Note that my contention is not of course that, in the case of interrelated disagreements, one should always treat one's dissenter as an epistemic equal regarding the disputed issues at hand, but only that one should not discard that he is one's peer so easily. As already observed, the main reason for Elga's questionable

\footnotetext{
11 Elga (2007: 492-494).

12 Cf. Christensen (2009: 760).
} 
move seems to be his desire to avoid at all costs any connection between EWV and across-the-board scepticism because the latter is a patently absurd stance.

According to Hilary Kornblith (2010), in the case of most philosophical matters as well as in certain perceptual and mathematical cases, peer disagreement gives one reason to suspend judgment entirely. He also claims that merely possible disagreement is not as epistemically significant as actual disagreement. The reason is that, if they were equally significant,

since there might always be people who disagree with one on any question at all, treating merely possible disagreement as on a par with actual disagreement would result in total skepticism. The worries generated by problems of disagreement, however, broad as they are, are not of this sort. So there seems to be an important asymmetry between actual disagreement and merely possible disagreement. ${ }^{13}$

Kornblith's argument seems to be the following:

(1) If actual and merely possible dispute are epistemically on a par, then one is required to suspend judgment in the face of merely possible dispute.

(2) If one is required to suspend judgment in the face of merely possible dispute, then one is required to endorse global scepticism.

(3) Global scepticism is unacceptable (because it is false, or implausible, or absurd, or incoherent).

Therefore,

(4) It is not the case that merely possible dispute is epistemically on a par with actual dispute.

Nowhere does Kornblith mention premise (3), but it is the only missing premise I can think of, unless what he has in mind is a claim about the negative pragmatic implications of global scepticism. In that case, my analysis of the second problem in the next section would also apply to this argument. But given the approach adopted by Kornblith in his paper, it is safe to assume that the hidden premise (3) expresses what he has in mind. ${ }^{14}$ Thus, what the argument states is that, since significant belief revision in the case of merely possible disagreement, but not in the case of actual disagreement, leads to an unacceptable view, then the two types of disagreement are not epistemically on a par. That is, whereas the sceptical challenge posed by actual disagreement

13 Kornblith (2010: 34).

14 In personal communication, Kornblith has now confirmed that my reconstruction of his argument is right, since he was indeed taking it for granted that global scepticism is unacceptable. 
is legitimate and reasonable, the sceptical challenge posed by merely possible disagreement is unacceptable. The important point for present purposes is that Kornblith believes that global scepticism is untenable, and that its untenability is so evident that there is no need to offer reasons-or, at least, he thinks it is unnecessary to do so in his discussion of the epistemic relevance of disagreement.

Many conciliationists manifest a deep concern to avoid wholesale or wideranging scepticism. ${ }^{15}$ The reason is that, if their positions entailed global or widespread suspension of judgment, this would be a clear proof that there is something fundamentally flawed about them. The cost of bearing any connection with such forms of scepticism is therefore too high. What many conciliationists and their critics have in common is not only the view that certain sceptical stances on peer dispute are untenable, but also the decision not to offer any reasons for this view. A possible reason for their disparaging attitude towards those stances is that they believe that their falsity, absurdity, or incoherence is evident to anyone with properly functioning cognitive faculties. Or perhaps they believe that the untenability of such forms of scepticism is something that has already been established for good. Or, as a reviewer has pointed out, they might think that the methodology of philosophy, as they are doing it, presupposes that we can know many of the things about which we are theorizing. ${ }^{16}$ Given that global or widespread scepticism contradicts this, it is ruled out of consideration by that methodology. Perhaps the methodology in question is the methodology of common sense, and so our task is to see how we can change common sense as little as possible while addressing philosophical puzzles. Given that global or widespread scepticism implies that all or most of common sense is wrong or unjustified, it is a non-starter. If this is what explains the attitude of (some of) those who in the disagreement literature

15 Another example is David Christensen, who considers whether his approach leads to an "objectionable" or "unacceptable" level of scepticism $(2007: 189,213)$. Although he recognizes that his split-the-difference view leads to suspension of judgment in many cases, he insists that peer disagreement does not always lead to scepticism and that it is unevenly distributed: whereas most mathematical, scientific, and everyday beliefs are not subject to significant peer disagreement, many moral, religious, political, and philosophical beliefs are (2007: 214). Christensen has also sought to provide a version of the principle of independence - on which conciliationism rests - that does not lead to "wholesale skepticism," something he regards as a "problem" or "vulnerability" (2009: 760-761; 2011: 15-16). As far as I can see, Christensen views any connection between conciliationism and wholesale scepticism as problematic because he believes the latter to be patently untenable.

16 As we will see in the next section, a methodology of this kind is explicitly adopted by Sanford Goldberg in his discussion of philosophical disagreement. 
dismiss global or widespread scepticism out of hand, the sceptic could make three remarks. First, they should at the very least make explicit what methodology they are following. Second, there is among non-sceptics entrenched disagreement about the correct methodology for philosophical inquiry, which is grist for the sceptical mill. Third, judging by the contemporary epistemological debate about common sense and scepticism, it is far from clear that appeal to common sense is a legitimate or effective defence against scepticism. ${ }^{17}$

Far from being exclusive to those working in the epistemology of disagreement, the opinion that scepticism is untenable is prevalent in the philosophical milieu. Now, when faced with the view that his stance is evidently false, absurd, or incoherent, the sceptic would argue that across-the-board or widespread suspension is perhaps an indefensible outlook, but that this is something that must be proven rather than taken for granted. Indeed, it seems that we should find such a dismissive view on scepticism much more surprising than we in fact do, if we simply attended to the part that scepticism has played in the history of philosophy. For, if it is so evidently false or absurd or incoherent, why have so many important historical figures undertaken its thoughtful refutation? Likewise, why are so many philosophers still deeply concerned with the problem of scepticism in different fields of philosophic inquiry? The answer seems to be that, as a philosophical stance, scepticism is worth examining and in need of refutation.

Someone might object that this is not the right answer, since most philosophers, especially contemporary analytic epistemologists, make a merely methodological use of sceptical arguments. They assume that the conclusions of these arguments are false, but claim that engaging sceptical arguments and determining where they go wrong can help us construct an accurate account of the nature of knowledge and evidence. ${ }^{18}$ Three remarks are in order. First, not all epistemologists (I know at least a couple) make a merely methodological use of sceptical arguments, and even if this were the unanimous practice in epistemology, in areas like metaethics and philosophy of religion those who

17 With regard to global suspension of judgment, another possible reason it is rejected is that such a stance would in the end be self-defeating or self-undermining: when the global sceptic finds out that most people believe that we should not suspend judgment in the face of most first-order disagreements, he should suspend judgment about whether he should suspend judgment. This charge, which I call the 'disagreeing about disagreement argument,' has now started to be discussed in detail in the literature on peer disagreement. I do not have the space to address it here, but in Machuca (Unpublished) I consider the charge, examine some conciliationist replies to it, and explain how a Pyrrhonian sceptic would respond to it.

18 See especially Greco (2000). It is perhaps worth noting that a similar methodological use of sceptical arguments was made by medieval philosophers: see Grellard (2004: 128-129; 2007: 342) and especially Perler (2010). 
discuss sceptical arguments view these arguments as posing serious challenges to the epistemic justification of our moral and religious beliefs. Second, one could take both the difficulties in pinpointing where sceptical arguments go wrong and the disagreement about exactly where they go wrong as an indication that it is probably too naïve or conceited or dogmatic to just take for granted that scepticism is false. Third, can we honestly affirm that philosophic inquiry in, e.g., epistemology, metaethics, and philosophy of religion has already offered knock-down arguments against all forms of radical scepticism so that we can simply take its incorrectness as established in our current investigations in each of those areas? In the specific case of the present epistemological discussions of disagreement, one observes that some well-respected philosophers are at a loss to explain why they are entitled to retain their beliefs, instead of suspending judgment, in the face of disagreements with people over whom they cannot discern any epistemic advantage. As we will see in the next section, one of the ways out they have found consists in appealing to some mysterious insight that they enjoy but that is unfortunately denied to their rivals.

My point in this section has been to emphasize that, in general, the parties to the current debate about peer disagreement have illegitimately dismissed out of hand the sceptical alternative. Even though in philosophical discussions one may be entitled to set aside certain issues, in the present case this means that the debate is greatly simplified and impoverished because of scepticism's intimate connection to the question of the epistemic relevance of disagreement in general. Once again, any disparaging or dismissive view on scepticism seems unfair, not because one denies the possibility of establishing that global or widespread suspension of judgment is in the end incoherent, absurd, or indefensible, but precisely because this is something that needs to be established rather than assumed.

\section{The Damaging Effects of Scepticism}

The second problem faced by any view that results in either global or widespread scepticism is that these forms of scepticism allegedly have damaging effects on both our philosophical worldviews and our everyday lives. This causes a strong fear of scepticism among both philosophers and laypersons, a fear detectable among those who discuss the epistemic significance of peer disagreement. For instance, with regard to EWV, Ernest Sosa observes:

But first we consider its implications for avoiding a dispiriting 'spinelessness' whenever we disagree with apparent peers. The importance of this issue is shown by how broadly it would bear on questions that matter to us in politics, religion, philosophy, and other such domains. It would be bad to have to suspend judgment on just about any controversial issue. ${ }^{19}$

19 Sosa (2010: 283-284). 
So wide-ranging suspension of judgment must be avoided because being epistemically spineless is $\mathrm{bad}$, a straightforward claim that conveys a commonly shared view about the threat posed by widespread scepticism. The same feeling of deep uneasiness towards scepticism is expressed by Peter van Inwagen. After reporting that David Lewis strongly disagreed with him regarding his beliefs that free will is incompatible with determinism and that unrealized possibilities are not physical objects, he points out:

I $d o$ believe these things. And I believe that I am justified in believing them. And I am confident that I am right. But how can I take these positions? I don't know. ... I suppose my best guess is that I enjoy some sort of philosophical insight ... that, for all his merits, is somehow denied to Lewis. And this would have to be an insight that is incommunicable ... for I have done all I can to communicate it to Lewis, and he has understood perfectly everything I have said, and he has not come to share my conclusions. But maybe my best guess is wrong. I'm confident about only one thing in this area: the question must have some good answer. For not only do my beliefs about these questions seem to me to be undeniably true, but ... I don't want to be forced into a position in which I can't see my way clear to accepting any philosophical thesis of any consequence. Let us call this unattractive position philosophical skepticism. ... I think that any philosopher who does not wish to be a philosophical skeptic ... must agree with me that this question has some good answer: whatever the reason, it must be possible for one to be justified in accepting a philosophical thesis when there are philosophers who, by all objective and external criteria, are at least equally well qualified to pronounce on that thesis and who reject it. ${ }^{20}$

The two explanations that van Inwagen offers for why he confidently holds certain beliefs even in the face of entrenched peer disagreement are actually intimately related. For it is his fear of scepticism that explains why, even when experiencing puzzlement as to the reason for his upholding views that he knows are rejected by equally clever and well-trained philosophers, he prefers to postulate some sort of philosophical insight that he is lucky to possess but that he cannot communicate to his opponents. In his eyes, there is no question that hypothesizing this philosophical insight is preferable to taking a sceptical stance. He seems to believe that anything is better than scepticism. It is his aversion to scepticism that renders him immune to the compelling considerations in favour of suspension of judgment in the case of deep-rooted peer controversies, even though he is fully conscious of them and recognizes that he cannot counter them on epistemic grounds. ${ }^{21}$ Precisely because he finds the mere idea of becoming a sceptic utterly unattractive or repellent, he thinks that there must be a conclusive justifying basis for his philosophical beliefs.

20 van Inwagen (1996: 138-139).

21 Cf. van Inwagen (2010: 28). 
I will come back to van Inwagen's move in a moment. For now it is important to note that, unlike the authors whose views I examined in the previous section, Sosa and van Inwagen reject scepticism, not because they believe it is patently false, absurd, or incoherent, but because they believe it has deeply negative implications for our intellectual and social lives.

A similar unease with scepticism can be detected in Sanford Goldberg's discussion of the epistemic justification of philosophical belief in relation to the problem of disagreement in philosophy. The reason for considering his view is that, as far as I can tell, his arguments should lead him to take a sceptical attitude towards the possibility of justified beliefs about disputed philosophical issues, yet he resists this outcome because of his reluctance to accept that all of his beliefs on such issues are unwarranted. Goldberg focuses his analysis on the following three claims that he views as individually plausible or defensible but jointly incompatible:

(1) Reliability is a necessary condition on epistemic justification;

(2) on contested matters in philosophy, my beliefs are not reliably formed;

(3) some of my beliefs on contested matters in philosophy are epistemically justified. ${ }^{22}$

I will leave aside both the question whether reliabilism is correct as a theory about epistemic justification and the question of the soundness of Goldberg's arguments for (2). The reason is that I am specifically interested in his reasons for holding (3) in the face of entrenched philosophical controversies. In other words, given that he endorses reliabilism and thinks that the arguments for (2) are sound, why does he continue to endorse (3)? He recognizes that none of the considerations he offers in support of this latter proposition-he is reasonably intelligent, has professional training in philosophy and experience doing philosophy, works hard and is careful in his investigations, has reasons for his views and subjects these reasons to both self-scrutiny and the scrutiny of others - ensures that his philosophical beliefs are true, nor that they are reliable. However, he maintains that it would be a curious outcome if none of his philosophical beliefs were justified, ${ }^{23}$ the reason being that,

where justified belief is possible, we might be forgiven for thinking that it is just such a person who will attain it. What sort of activity is philosophy anyway, that it attracts reasonably intelligent people into spending their intellectual lives toiling away, only to be systematically thwarted in their efforts at justified belief $?^{24}$

22 Goldberg (2009: 105).

23 It should be observed that Goldberg (2009: 111) passes without comment from talking about the justification of his beliefs about contested matters in philosophy to talking about the justification of his philosophical beliefs tout court.

24 Goldberg (2009: 111). 
Besides failing to understand how Goldberg can claim that some of his philosophical beliefs are justified, despite recognizing that the considerations in favour of this claim do not ensure their reliability, I must confess that I do not see why the fact that intelligent (even brilliant) people devote themselves to philosophy entails that some of their beliefs about disputed philosophical issues are epistemically justified. Is persistent, deep-rooted, widespread disagreement not an undeniable fact about philosophy? Is it not a fact that brilliant philosophers deeply disagree with one another on, at the very least, a great many issues? Is the common claim that there is no real progress in philosophy (except for areas such as logic) arbitrary or capricious? The only strong reason I can think of for resisting scepticism about philosophy is that its effects are appalling, and Goldberg seems to be motivated by such a reason when at the end of his article he claims:

The odd man out would appear to be (3), but this leaves me-us - in an unhappy position ... neither you nor I are warranted in making assertions on controversial matters of philosophy. This will require either a wholesale reconfiguration of the practice of philosophy (don't assert anything!), or else a recognition that when you and I do philosophy ... we are systematically behaving in an unwarranted fashion. ${ }^{25}$

And in a note concerning the option to stop making assertions, he adds:

Perhaps the ancient skeptics were right after all, at least in practice: we have no business claiming philosophical knowledge. Though neither we nor they should actually assert this. Is this a happy position? ${ }^{26}$

Goldberg's reason for not embracing metaphilosophical scepticism is simply that he is unwilling to accept the unpleasant and shocking implications of the claim that all of his beliefs on controversial philosophical matters are unfounded or unwarranted. He is not disposed to admit that philosophical inquiry might be pointless insofar as its aim is conceived of as the acquisition of knowledge or justified belief, i.e., as the attainment of truth. At times it seems that the type of scepticism he has in mind consists in the denial of the possibility of philosophical knowledge or justified philosophical belief or the possibility of discovering truth. Of course, this philosophical view is self-defeating or self-undermining if it asserts that we are unjustified in making philosophical assertions. There is, however, another variety of scepticism - the Pyrrhonian variety - that is the one to which Goldberg alludes in the second quote above. The Pyrrhonian sceptic limits himself to reporting that he has so far been unable to acquire philosophical knowledge or justified philosophical belief or to attain

25 Goldberg (2009: 116).

26 Goldberg (2009: 116 n. 19). 
the truth regarding the matters he has investigated. Also, he does not present his suspension of judgment as a philosophical view that he believes or asserts to be epistemically or rationally grounded. Rather, he observes $(i)$ that his own suspension of judgment is a state of mind in which, as a matter of fact, he finds himself when confronted with apparently equipollent arguments, and (ii) that his rivals' own theories commit them to suspending judgment. ${ }^{27}$ I do not think, however, that this form of scepticism would be appealing to Goldberg, just as it is clearly unappealing to the great majority of philosophers. In fact, he explicitly says that the outlook recommended by the ancient sceptics is not a happy position. As already noted, Goldberg resists taking a stance that seems to be required by his own arguments. Perhaps he is not to be blamed for his reluctance to adopt a sceptical stance, given what is at stake for him, i.e., given the value that philosophical inquiry practiced in a non-sceptical manner has for him. ${ }^{28}$

In sum, the reason global or widespread suspension of judgment is to be rejected as an unattractive position is that it has negative consequences for important areas of our lives. This is a quite common stance on scepticism among both philosophers and laypersons, who usually discard either local or global forms of scepticism because their implications would be unwelcome or disastrous or depressing or unfortunate. It is thought, frequently not in an explicit way, that, given these negative implications, scepticism must be false or should not be taken into account as a suitable philosophical stance. Indeed, quite often we hear or read that atheism and religious agnosticism are to be rejected as real alternatives because a world without the divine or a life of ignorance about the divine would make our existence pointless or meaningless; that moral anti-realism and moral agnosticism are false because otherwise everything would be permitted and social order would crumble; that denying or suspending judgment about the rational justification of trust is unacceptable because it depicts a terrible picture of human relationships; that denying or suspending judgment about the possibility of knowledge or justified belief in general is to be rejected because it leaves us in world of total unbearable uncertainty. And hence scepticism is almost always held in an extremely low regard.

What the aforementioned reactions against scepticism show is that a considerable number of people have pragmatic reasons for rejecting or ignoring it. For they believe that, if the sceptic's stance is correct, then it represents a hindrance to the attainment of certain goals they take to be crucial to their intellectual or social lives. I have no problem with this belief because whether

27 This is not the place to defend my interpretation of the ancient Pyrrhonist's stance, in particular his outlook on suspension of judgment and rationality. I have done so in, e.g., Machuca (2011) and (2013a).

28 It should be noted that Goldberg is now much less reluctant to adopt a sceptical stance: see Goldberg (2013a) and (2013b). 
scepticism has negative pragmatic implications or effects is largely a psychological matter. I mean, whether the realization that, e.g., one cannot determine whether there exist objective moral values will lead a person to depression, distress, or anarchy will depend on that person's psychological makeup. The majority of people seem to believe that they would undergo strongly unpleasant feelings were they to suspend judgment across the board, whereas the secondcentury sceptic Sextus Empiricus tells us that the ancient Pyrrhonist unexpectedly attained the state of undisturbedness (ataraxia) in matters of opinion upon suspending judgment about all matters of inquiry. ${ }^{29}$ So what I am criticizing is rather that pragmatic reasons are sometimes mistaken for epistemic reasons. One must keep in mind that, in seeking to determine which doxastic attitude is rationally required in the face of peer dispute or extensive persistent disagreement, the parties to the debate are concerned, not with which doxastic attitude is pragmatically justified, but with which doxastic attitude is epistemically supported by the total body of available evidence. Once again, the alleged fact that the implications of scepticism are deeply appalling because they threaten our intellectual or social lives may constitute a strong pragmatic reason for rejecting it, but other reasons are needed if we want to reject it on epistemic grounds.

Keeping the distinction between the two kinds of reasons in mind also allows us to see that pragmatic reasons against scepticism are advanced because there are at least prima facie strong epistemic reasons in its favour. Indeed, if scepticism were patently incoherent or false, then our lives would not possess any of the depressing characteristics allegedly entailed by it. That is, if scepticism could be readily defeated on epistemic grounds, then there would be no reason to worry about its negative practical implications. If this is correct, then if one affirms that any view that leads to global or widespread suspension of judgment faces the pragmatic problem under consideration, then one cannot maintain that it also faces the first problem examined in the previous section, for the simple reason that scepticism would not be a patently incoherent or false stance.

Most readers will probably find the preceding remarks obvious or elementary. For it is plainly a non sequitur to argue that the excruciating practical and emotional effects of scepticism entail that it is false or that it ought not to be considered as a valid philosophical alternative. However, given the widespread use of that line of argument, it is necessary to insist that epistemological discussions of disagreement must investigate, not whether scepticism has useful or beneficial effects, but whether it is the alternative best supported by the total body of available evidence. ${ }^{30}$ If scepticism cannot be refuted and if it has any

29 Cf. Machuca (2006: 124).

30 Another clear recent example of an attempt to answer disagreement-based scepticism by appeal to pragmatic reasons is found in Lynch (2012: Chapter 5), on which see Machuca (2013b: 309-310). 
of the aforementioned appalling consequences, so be it. At least those who are in the business of philosophy should swallow their fear and follow where the arguments lead.

It has been pointed out to me that other readers, by contrast, will not find the distinction between epistemic and pragmatic reasons obvious at all, since they will argue that recent discussions of pragmatic encroachment should make one suspicious of the sharp distinction between those two types of reasons. I cannot address here the vexed question whether what we ought to believe is in part dependent upon practical considerations regarding what we ought to do. Let me just point out that, although it is a controversial view on justification, at least quite a few of those engaged in the current debate about the epistemic significance of disagreement seem to be committed to evidentialism, according to which what one ought to believe depends upon one's total evidence:

\section{Evidentialism}

$\mathrm{S}$ is epistemically justified in adopting doxastic attitude A towards proposition $p$ at time $t$ if and only if S's total body of evidence at $t$ supports adopting A towards $p .^{31}$

In the disagreement literature, the discussion is couched in terms of whether both the first-order and the higher-order evidence bearing on the target proposition justify believing, disbelieving, or suspending judgment about that proposition. Or, on a fine-grained approach to doxastic attitudes, the relevant question is what degree or level of credence in the target proposition is best supported by one's total evidence. Given that at least quite a few epistemologists working on disagreement follow the traditional, purely 'intellectualist' picture of epistemic justification, it seems legitimate to criticize them whenever they draw epistemic conclusions on the basis of pragmatic reasons. Moreover, even those who endorse pragmatic encroachment do not claim that pragmatic reasons are epistemic reasons, but only that the stakes can affect how good one's epistemic reasons need to be.

My critical analysis of the second problem allegedly faced by conciliationism may be taken as an instance, within the context of the literature on disagreement, of the dissatisfaction with pragmatic responses to scepticism expressed by certain contemporary epistemologists. ${ }^{32}$ It should be noted, though, that the pragmatic replies in question are two distinct versions of a well-known charge already levelled in antiquity against both Pyrrhonian and Academic scepticism, namely, the inactivity or apraxia objection. According to the pragmatic response that has been discussed in the epistemology literaturewhich is advanced mainly against external world scepticism-either the sceptic's actions are inconsistent with the conclusion of his argument or his actions

31 On evidentialism, see especially Conee \& Feldman (2004).

32 See, e.g., Greco (2000: 64-65). 
show that he does not actually believe the conclusion. By contrast, the pragmatic response to scepticism that I have discussed in this section maintains that global or widespread scepticism should be rejected because it makes impossible a life that is good, tolerable, or worth living.

\section{Concluding Remarks}

I have argued that those engaged in the current discussions of the epistemic significance of disagreement rule out radical scepticism as a serious alternative for two reasons. The first is that global or widespread suspension of judgment is so patently untenable, absurd, or incoherent that it can simply be ignored. The second reason is that the implications of radical scepticism are so appalling, worrisome, or hard to digest that one had better avoid it. I have claimed that these two reasons are arbitrary and weak. First, even if global or widespread suspension of judgment is indefensible, this is not evident, but rather something that must be established. Otherwise, one could not explain either the crucial role scepticism has played in the history of philosophy or the significant part it continues to play particularly in epistemology, metaethics, and philosophy of religion. Second, even if scepticism is a real threat to our intellectual and social lives, we must be careful to distinguish between epistemic and pragmatic reasons for rejecting it. For even if it hinders the attainment of (some of) our practical and intellectual goals, this by itself does not entail that scepticism is epistemically unjustified, but only that it is instrumentally unjustified.

Let me make clear where I stand: I do not think that global or widespread suspension of judgment is either a ludicrous philosophical outlook that can simply be dismissed out of hand or a serious philosophical disease against which we must be immunized. Scepticism is a possible outcome of many careful and thorough inquiries, and hence any serious inquirer needs to deal with it to see if sceptical doubts, aporias, or challenges can be overcome on epistemic grounds. We cannot just sweep it under the carpet because we find it threatening. Or we can, but in that case we should at least make it clear that we are not refuting it on epistemic grounds. Given that we are in the business of philosophy, we should probably follow the arguments where they lead, even if this means ending up in a state of total uncertainty.

I will conclude by addressing two possible objections. It might first be argued that the reason global or widespread scepticism has been dismissed out of hand by the authors who focus on peer disagreement is that such scepticism is not a conclusion that can plausibly be reached on the basis of peer disagreement. Although this line of argument has been followed by some authors, ${ }^{33}$ it is not followed by the authors whose views I have considered. These authors, some of whom are non-conciliationists and others conciliationists, think that conciliatory views on peer dispute either do lead or may lead to either global

33 E.g., King (2012) and (2013). 
or widespread scepticism. Whereas the non-conciliationists in question take the patently untenable or threatening character of such forms of scepticism as a reason for rejecting conciliationism, the conciliationists in question take it as a reason for formulating their views in such a way as to not lead to them.

It might also be asked whether, even if one grants that global or widespread scepticism has been unduly ignored in the contemporary literature on disagreement, anything interesting follows for the current debate. In other words, would taking scepticism (more) seriously change the debate in a significant way? Why does scepticism matter at all? For one, recognizing that certain forms of scepticism have been unduly dismissed out of hand requires that those who deny the viability or tenability of global or wide-ranging suspension of judgment put forth arguments that establish that it is indeed the case that such forms of scepticism are unviable or untenable. Doing so would by itself considerably enrich the current debate over the possible sceptical implications of disagreement. And if such arguments were found unconvincing or implausible or unsound, then all those involved in the debate would have to seriously consider whether reflection on peer dispute or on widespread persistent disagreement does lead to suspension of judgment about the issues that are subject to these kinds of disagreement. If it did, then we would have to admit, albeit reluctantly, that such types of dispute provide an undefeated defeater for at least a considerable number of our beliefs.

Acknowledgements: A distant ancestor of this paper was presented at the University of Miami in April 2012. I am grateful to the audience for stimulating discussion. I also wish to thank Jon Matheson, John Turri, Mark Walker, and the two anonymous reviewers for Dialogue for their comments on previous versions.

\section{References}

Christensen, David

2007 "Epistemology of Disagreement: The Good News," Philosophical Review 116: 187-217.

Christensen, David

2009 "Disagreement as Evidence: The Epistemology of Controversy," Philosophy Compass 4: 756-767.

Christensen, David

2011 "Disagreement, Question-Begging and Epistemic Self-Criticism," Philosophers' Imprint 11/6: 1-22.

Conee, Ernest \& Richard Feldman

2004 Evidentialism: Essays in Epistemology. New York: Oxford University Press.

Elga, Adam

2007 "Reflection and Disagreement," Noûs 41: 478-502. 
Enoch, David

2010 "Not Just a Truthomether: Taking Oneself Seriously (but not Too Seriously) in Cases of Peer Disagreement," Mind 119: 953-997.

Feldman, Richard

2006 "Epistemological Puzzles about Disagreement." In S. Hetherington (ed.), Epistemology Futures, 216-236. New York: Oxford University Press.

Feldman, Richard

2007 "Reasonable Religious Disagreements." In L. Antony (ed.), Philosophers without Gods: Meditations on Atheism and the Secular Life, 194-214. Oxford: Oxford University Press.

Feldman, Richard

2009 "Evidentialism, Higher-Order Evidence, and Disagreement," Episteme 6: 294-312.

Goldberg, Sanford

2009 "Reliabilism in Philosophy," Philosophical Studies 142: 105-117.

Goldberg, Sanford

2013a "Defending Philosophy in the Face of Systematic Disagreement."

In D. Machuca (ed.), Disagreement and Skepticism, 277-294. New York: Routledge.

Goldberg, Sanford

2013b "Disagreement, Defeat, and Assertion." In D. Christensen \& J. Lackey (eds.), The Epistemology of Disagreement: New Essays, 167-189. Oxford: Oxford University Press.

Greco, John

2000 Putting Skeptics in Their Place. Cambridge: Cambridge University Press.

Grellard, Christophe

2004 “Comment peut-on se fier à l'expérience? Esquisse d'une typologie des réponses médiévales au problème sceptique," Quaestio 4: 113-135.

Grellard, Christophe

2007 "Scepticism, Demonstration and the Infinite Regress Argument (Nicholas of Autrecourt and John Buridan)," Vivarium 45: 328-342.

Kelly, Thomas

2005 "The Epistemic Significance of Disagreement," Oxford Studies in Epistemology 1: 167-196.

Kelly, Thomas

2010 "Peer Disagreement and Higher-Order Evidence." In R. Feldman \& T. Warfield (eds.), Disagreement, 111-174. New York: Oxford University Press.

King, Nathan

2012 "Disagreement: What's the Problem? or A Good Peer is Hard to Find," Philosophy and Phenomenological Research 85: 249-272. 
King, Nathan

2013 "Disagreement: The Skeptical Arguments from Peerhood and Symmetry." In D. Machuca (ed.), Disagreement and Skepticism, 193-217. New York: Routledge.

Kornblith, Hilary

2010 "Belief in the Face of Controversy." In R. Feldman \& T. Warfield (eds.), Disagreement, 29-52. New York: Oxford University Press.

Lynch, Michael

2012 In Praise of Reason. Cambridge, MA: MIT Press.

Machuca, Diego

2006 "The Pyrrhonist's $\alpha \tau \alpha \rho \alpha \xi i ́ \alpha$ and $\varphi \imath \lambda \alpha v \theta \rho \omega \pi i \alpha, "$ Ancient Philosophy 26: 111-139.

Machuca, Diego

2011 "Pyrrhonism and the Law of Non-Contradiction." In D. Machuca (ed.), Pyrrhonism in Ancient, Modern, and Contemporary Philosophy, 51-77. Dordrecht: Springer.

Machuca, Diego

2013a “Pyrrhonism, Inquiry, and Rationality," Elenchos 34: 201-228.

Machuca, Diego

2013b Review of Lynch 2012, Philosophy in Review 33: 308-311.

Machuca, Diego

2013c “Editor's Introduction.” In D. Machuca (ed.), Disagreement and Skepticism, 1-23. New York: Routledge.

Machuca, Diego

Unpublished "A Neo-Pyrrhonian Response to the Disagreeing about Disagreement Argument."

Matheson, Jonathan

2009 "Conciliatory Views of Disagreement and Higher-Order Evidence," Episteme 6: 269-279.

Perler, Dominik

2010 "Skepticism." In R. Pasnau (ed.), The Cambridge History of Medieval Philosophy, 384-396. Cambridge: Cambridge University Press.

Plantinga, Alvin

2000 "Pluralism: A Defense of Religious Exclusivism." In K. Meeker and P. Quinn (eds.), The Philosophical Challenge of Religious Diversity, 172-192. New York: Oxford University Press.

Sosa, Ernest

2010 "The Epistemology of Disagreement." In A. Haddock, A. Millar, \& D. Pritchard (eds.), Social Epistemology, 278-297. Oxford: Oxford University Press.

Thune, Michael

2010 "'Partial Defeaters' and the Epistemology of Disagreement," The Philosophical Quarterly 60: 355-372. 
488 Dialogue

van Inwagen, Peter

1996 "It is Wrong, Everywhere, Always, and for Anyone, to Believe Anything upon Insufficient Evidence." In J. Jordan \& D. Howard-Snyder (eds.), Faith, Freedom, and Rationality, 137-153. London: Rowman \& Littlefield.

van Inwagen, Peter

2010 “We're Right. They're Wrong.” In R. Feldman \& T. Warfield (eds.), Disagreement, 10-28. New York: Oxford University Press. 